\title{
睡眠中の情報処理
}

\author{
国立精神・神経センター精神保健研究所 \\ 鈴木 博之
}

\section{Information processing during sleep}

\author{
Hiroyuki SuzuKI \\ National Institute of Mental Health, NCNP \\ 4-1-1 Ogawa-higashi, Kodaira, Tokyo 187-8502, Japan
}

Recent studies have provided evidence that information processing occurs during sleep as well as in the daytime. This paper reviews the literature on information processing during sleep from the viewpoints of 1) input: response to external stimuli during sleep, 2) processing: consolidation and improvement of learned memory during sleep, and 3) output: temporal features of dream occurrence and characteristics of dream content. Although during sleep the ability to respond to external stimuli decreases, psychological functions, such as attention and motivation, are maintained. Sleep is required after training in order to improve certain types of procedural and declarative memory. Dreaming occurs frequently in the morning, and altered association of semantic memories is related to the unique quality of dream contents. Progress in the study of information processing during sleep will provide further understandings of human cognitive function and mental activity. (Japanese Journal of Physiological Psychology and Psychophysiology, 25(1) : 17-34, 2007.)

Key words : information processing, memory improvement, procedural memory, declarative memory, dream

【要 約】 近年の研究は睡眠中にも覚醒時と同様に情報処理が行われていることを示している。本論文は睡眠中 の情報処理を 1) 入力 : 睡眠中の外部刺激への反応, 2) 処理 : 睡眠中に起こる学習した記憶の固定と向上, 3) 出力 : 夢出現の時間的特性と夢内容の特徵, の観点から概観する。睡眠中は外部の刺激への反応が減少するが, 注意や 動機づけといった心理的機能は維持されている。ある種の手続き記憶と宣言的記憶の向上には練習後の睡眠が必 要である。夢は朝方に頻繁に起こり, 変化した意味記憶の連合が独特な夢の内容と関連している。睡眠中の情報 処理に関する研究の発展は人間の認知機能と心的活動のさらなる理解を提供するであろう。

2006.12.6 受稿, 2007.1.29 受理 


\section{はじめに 一睡眠中の情報入力, 処理, 出力一}

情報処理とは主に外部からの情報を生体が入力し， 操作・処理を行った後, 出力する一連の過程を意味す る。

我々は日常生活において意識的，無意識的に様々な 情報処理を行っている。各感覚器官から入力される情 報に対し, 判断, 決定を行い, 身体運動, 言語などの 反応を出力する過程は我々の生活そのものといっても よい。一方，睡眠中にはこれらの情報処理過程が休息 状態であると考えている人も多いであろう。確かに睡 眠中は瞼を閉じることで視覚情報を遮断し, 聴覚, 皮 膚感覚などの閾値も高くなることで入力は遮られ, 休 息している脳の中では情報の処理は行われず，行動の 出力も行われていないように見える。しかし，睡眠中 にも情報は入力され，処理され，出力されているので ある。近年の研究により, これらの睡眠中の情報処理 過程が明らかになってきており, 睡眠が単なる休息状 態ではなく独自の情報処理過程を持っていることが示 されている。

本稿では, 睡眠中の情報処理過程として，1）睡眠 中の情報入力 : 睡眠中に呈示される情報に対する処理, 2) 睡眠中の情報処理 : 睡眠による記憶の向上, 3) 睡 眠中の情報出力：夢見体験に現れる記憶, の 3 点につ いて述べる。

\section{1 睡眠中の情報入力}

睡眠中には外部刺激の入力及び反応性が低下するこ とは日常生活でよく経験することであろう。例えば, $\mathrm{CD}$ を聴きながら眠ってしまったときに 2 曲目までし か聴いたことを覚えていない, 授業中眠っている学生 に声をかけてもなかなか返事をしない，といったこと がある。これらは睡眠の代表的な特徴の一つである。 脳波によって睡眠状態を客観的に測定できなかった時 代には, 覚醒させるのに要する刺激の強さが睡眠深度 を表す一つの指標であった。しかし, 眠っている間は 外部からの入力情報が完全に遮断されるかというとそ うではない。目覚まし時計の音で目が覚めるのは音が 入力されているからであり, 眠っていてよほどのこと がない限りベッドから落ちることがないのは, 眠って いる間もべッドの縁を感じ取ることができるからであ る。

\section{1 睡眠中の刺激への反応}

睡眠中に入力される刺激への反応性と脳波による睡 眠深度との関係は古くから検討されている。Okuma, Nakamura, Hayashi, \& Fujimori (1966) は睡眠中の被験 者に対して光刺激を数回呈示し, その回数だけボタン を押して反応させる課題を行つた。睡眠段階の進行に 伴い正反応は減少し, 特に睡眠段階 1 から 2 にかけて 急激な減少 (83\%から 29\%) がみられる。徐波睡眠 (睡 眠段階 $3+4)$ での正反応はほとんど無く $(1 \%)$, 外 部からの視覚情報入力に対し適切に反応することが不 可能であることが分かる。REM 睡眠での正反応は 48 \%と睡眠段階 1 から 2 の間であり, 情報入力に対する 反応という観点からは浅いNREM 睡眠と同等である ことが分かる。音刺激を用いた同様の実験 (Rechtschaffen, Hauri, \& Zeitlin, 1966) でも REM 睡眠 (55.7\%) は睡眠段階 2(62\%) と同等の反応率であり, 徐波睡眠では $19.4 \%$ と大きく低下している。しかし, 光刺激と比べその反応率は高く, 睡眠中は視覚刺激よ りも聴覚刺激に対する情報入力が維持されていること がうかがえる。

睡眠中の感覚入力減少の生理学的背景として, 睡眠 時には視床の刺激応答性が低下し, 感覚器官から受け 取った情報を大脳皮質に中継する機能が顕著に低下す る「感覚ゲーティング」という現象が起こっているこ とが示されている(村上・森, 2005)。この視床の応 答性の低下によって大脳皮質が受け取る情報が低下し, 睡眠中の情報入力の低下が起こっていると考えられる。

\section{2 睡眠中の注意維持}

赤ん坊と一緒に眠っている母親は, 雨, 風などの騒 音では目覚めないが, 少しでも赤ん坊が泣きだすと目 覚める，といった話はよく耳にする。眠っている間も 重要な情報に対しては反応し, 不要な情報には反応し ないのである。これは睡眠中にも入力された情報を弁 別する機構が働き，大事な情報とそうでない情報をよ り分ける処理, すなわち注意や意志が維持されること を意味している。

カクテルパーティー効果の例にあるように, 他のこ とをしているときでも自分の名前を呼ばれるとつい注 意を向けてしまう。これは睡眠中も同様である。 Langford, Meddis, \& Pearson (1974) は眠っている被験 者に First nameを録音した音声 (有意味音), もしく 
はその音声の逆回転再生音（無意味音）を聞かせて， ボタン押しによる反応をさせることで睡眠中の注意機 構を検討している。その結果, 無意味音では睡眠段階 2 において 76.0 秒だった反応時間が, 有意味音では 27.9 秒に短縮している。REM 睡眠では 49.7 秒から 10.6 秒とさらに大きく短縮した。アルファ波の出現を 指標とした脳波的覚醒も有意味音に同様の影響がみら れ，睡眠段階 2 では覚醒反応出現潜時が 57.7 秒から 19.2 秒, REM 段階では 44.1 秒から 5.7 秒とより顕著 な短縮がみられた。このように睡眠中でも，自分にと つて意味のある情報に対しては無意識的な注意力が働 いていることが分かる。

\section{3 意志, 動機づけの効果}

特定の刺激に対して注意するよう指示された場合, 睡眠中にはどの程度注意を維持できるのだろうか。 Williams, Morlock, \& Morlock (1966) は睡眠中の被験者 に2 種類の音を聞かせ，あらかじめ指示した一方の刺 激に対して反応させる弁別反応課題を行った。正反応 は睡眠段階が進むに従って減少し, REM 睡眠で最も 低くなった。しかし同様の実験を「弁別刺激に反応し なかった場合警告音が鳴り, 足に電気ショックが流れ る」と教示すると反応率は上昇した。特に REM 睡眠 中の反応は約 5\%から約 45\%に増加した。この結果は, 音刺激が脳波の覚醒反応（アルファ波の出現）を伴わ ない場合にのみみられたことから，被験者は睡眠を維 持しながら弁別を行っていることが示されている。意 志・動機づけの影響は，NREM 睡眠中よりもREM 睡 眠中に大きいことが分かる。

REM 睡眠中に現れる注意・動機づけの効果は事象 関連電位 (event-related potential: ERP) を用いた研究に よっても検討されている。ERPの測定は必ずしも被 験者の刺激に対する反応を必要としないため, 睡眠中 の入力情報に対する脳内の処理をより客観的に検討す ることができる。Takahara, Nittono, \& Hori (2006) は, 睡眠中に呈示された音を聞き分けるように教示した条 件（注意条件）と聞き流すように教示した条件で ERP 成分を比較した。REM 睡眠中では, 注意と関倸 する P400 成分の振幅が注意条件で大きかったが, NREM 睡眠段階 2では条件間の差はみられなかった。 よって，REM 睡眠中には NREM 睡眠中よりも入力さ れる情報に対する注意機構が働いていることを示唆し
ている。しかし，この ERPの反応は REM 睡眠中でも 急速眼球運動が出現しない期間 (tonic REM) にのみみ られ，頻繁に急速眼球運動が出現する期間 (phasic REM) にはみられなかった。このことから，REM睡眠中に は外部からの情報入力が処理される期間と，行われな い期間があると考えられる。phasic REM 中には夢見 体験など内的な情報処理が行われるため, 外的な情報 入力に対しては処理が行われないといった可能性が考 えられる

\section{4 睡眠中に入力された情報を思い出せるか？}

夜中に電話で起こされて会話をしたにもかかわらず, 次の日になって電話をかけた友人から電話の内容を指 摘されても全く思い出せないことがある。この体験は 睡眠中に入力された情報に対し，その場での処理は可 能であるが，その情報はその後保持されないことを表 している。Badia, Harsh, Balkin, O'Rourke, \& Burton (1985) は睡眠中に呈示される音刺激に対し深呼吸で反 応するように被験者に指示した。被験者は夜間を通じ て 50-100 回音刺激に対して反応したにもかかわらず, 朝目覚めたときに自分が何回反応したと思うか訪ねら れると，6-8 回と答えた。このように，睡眠中に入力 された情報には反応することはできるが，朝まで保持 されることはまれであることが分かる。しかし，睡眠 中に入力された情報を思い出せないからといって, 全 く記憶に残っていないとは限らない。Wyatt, Bootzin, Anthony, \& Bazant (1994) は睡眠中に呈示された単語対 を思い出すように指示されると，呈示されてから 10 分後には再生できないが, 手がかりを与えると思い出 せることを報告している。すなわち，睡眠中に呈示さ れた情報は意識して思い出すことができる顕在記憶と しては保存されないが，思い出すことを意識しない潜 在記憶としては保存されている可能性が示唆されてい る。眠っているからと言って，その人に言えないよう なことを周りでおしゃべりしていると，後で目覚めた ときに，その内容を何かのきっかけで思い出すかもし れないのである。

睡眠中の情報入力は全般的に低下する。しかし，睡 眠中にも外界からの情報に対する注意が維持されてい ることが上記の結果により示されている。この機能は 睡眠中も全くの無防備状態になることを避ける生存維 持機構が働いていることを表すものであろう。 


\section{2 睡眠中の情報処理 一睡眠による記憶の向上一}

テスト勉強をした後は少しでも眠った方がよく覚え る，という話は誰しも一度は耳にしたことがあるだろ う。近年の研究により, 学習後に眠ることは, 眠気や 疲れを取り除き次の日の試験中のコンディションを整 えるだけでなく，学習した記憶をより強固なものにす る効果があることを示している。すなわち, 目覚めて いるときに何回も繰り返し記銘することによって達成 できると考えられてきた学習のプロセスが, それらの 覚醒時に行う努力の最中にではなく, その後の睡眠中 に行われているということである。もちろん, 覚醒中 の努力無しに学習は起こりえないが, 学習の後に眠り という状態を脳に与えることが, よりよい学習効果を もたらすということである。このことから，睡眠は休 息であるという従来の考え方から，睡眠は促進である という新たな見解が得られるようになった。

古くから記銘後の睡眠の効果について検討は行われ ており, 1924 年に Jenkins \& Dallenbachは無意味綴り を記銘した後に眠った方が覚醒を維持するよりも 8 時 間後の再生率が優れていることを表した。しかし, 彼 らの実験には方法論的な問題点があるために, 睡眠が 記憶の向上をもたらしているかは不明だった。睡眠中 に記憶が向上していることを示すためには以下の二つ の交絡変数を取り除く必要がある。1) 眠らないこと による眠気, 疲労の影響: 徹夜をして試験に臨むこと は当然ながら眠気・疲れによる悪影響を受ける。眠る ことによる成績向上は睡眠中に記憶が向上するためで はなく, テストを受けるときの心身の状態が良く, 思 い出しゃすかったためかもしれない。2) 干渉効果の 影響: 学習後に覚醒していれば, 当然様々な情報の入 カにさらされる。テレビを見る，会話をする，本を読 むなど, 記銘後に加えられる情報が, 学習した記憶を 干渉することによって眠ったときよりも成績が低下す るのかもしれない。学習後は眠る, 眠らないに関わら ず，情報を遮断していれば良いのではないか。もし， 睡眠中に記憶の向上が起こっているとするならば, 試 験時の眠気, 疲れや情報の遮断とは関係なく, 睡眠中 の脳内の状態が学習を起こしている証拠を示さなけれ ばならない。

近年の心理学, 精神生理学の研究は睡眠中の情報処 理以外の交絡変数を統制して, 特定の睡眠状態や睡眠 中の脳内活動が記憶の保持, さらには向上に有用であ
ることを示している。この章ではまず睡眠と記憶の関 係を検討するために用いられる実験方法について, 次 に課題に用いられる記憶の種類, 最後に手続き記憶と 宣言的記憶のそれぞれに与える睡眠の効果について述 ベる。

\section{1 睡眠と記憶研究の方法}

これまでに睡眠と記憶の関係を実験的に検討するた めに様々な方法が用いられている。各実験方法には睡 眠以外の交絡変数が含まれるため, 一つの方法だけで は睡眠が記憶を向上させるという結論を導き出すこと はできない。しかし，いくつかの方法を併用すること によりそれぞれが持つ方法論的問題点を補い，より強 固な証拠を得ることができる。大きく分けて, 睡眠後 と覚醒後の課題成績を比較する方法と, REM・NREM 睡眠など特定の睡眠状態の影響を検討する方法がある。 (1) 睡眠条件と覚醒条件の比較

(a) 記銘・練習後に，眠る条件と眠らない条件（断眠 条件）間で, テストを行い成績の向上量を比較：学習 後の睡眠がその後の記憶内容に与える影響を検討する 方法である (Figure 1A)。問題点は, 断眠条件では朝 のテスト時の眠気, 疲労, ストレスが大きく, 断眠に よって睡眠中に起こるはずの記憶の向上が抑えられた のか, 眠気などの影響によって想起能力の低下が起こ つたのか判断できないことである。この問題点を解決 するために, 記銘・練習からテストまでの期間を 2 , 3 日あけて, 断眠条件では回復睡眠後の状態で比較す る方法もある (Figure 1B)。この方法では断眠直後の 身体的・心理的負荷を取り除き, 課題後の睡眠の効果 を検討することができる。ただし，練習から再テスト までの期間が 24 時間以上空いてしまうため, 練習の 効果がそれ以上継続することが前提となる。

(b) 夜練習・朝テスト条件と, 朝練習・夜テスト条件 で比較：例えば, 夜の 21 時に練習し, 夜眠つた後の 朝 9 時にテストを行う睡眠条件と, 朝の 9 時に練習し てその日の夜 21 時にテストを行う覚醒条件を比較す るものである (Figure 1C)。練習とテストの時間間隔 を等しくすることで睡眠の影響を検討する。問題点と して, 朝と夜の課題成績の違いが交絡要因となること, 覚醒時における行動, 記憶活動が入力されることによ り，対象とする記憶が干渉される可能性がある。

(c) (1)朝・昼 - 夜 (睡眠無し条件), (2)朝・夜・朝, 
(3)夜・朝・夜の 3 条件間で比較：各条件において 3 回 課題を繰り返すことにより, 順序効果, 時間経過によ る記憶向上の様子と睡眠の効果を同時に検討すること ができる（Figure 1D）。夜から朝にかけての向上量が 昼間の向上量よりも大きいことが認められれば，睡眠 による記憶向上効果があると考えられる。時刻によつ

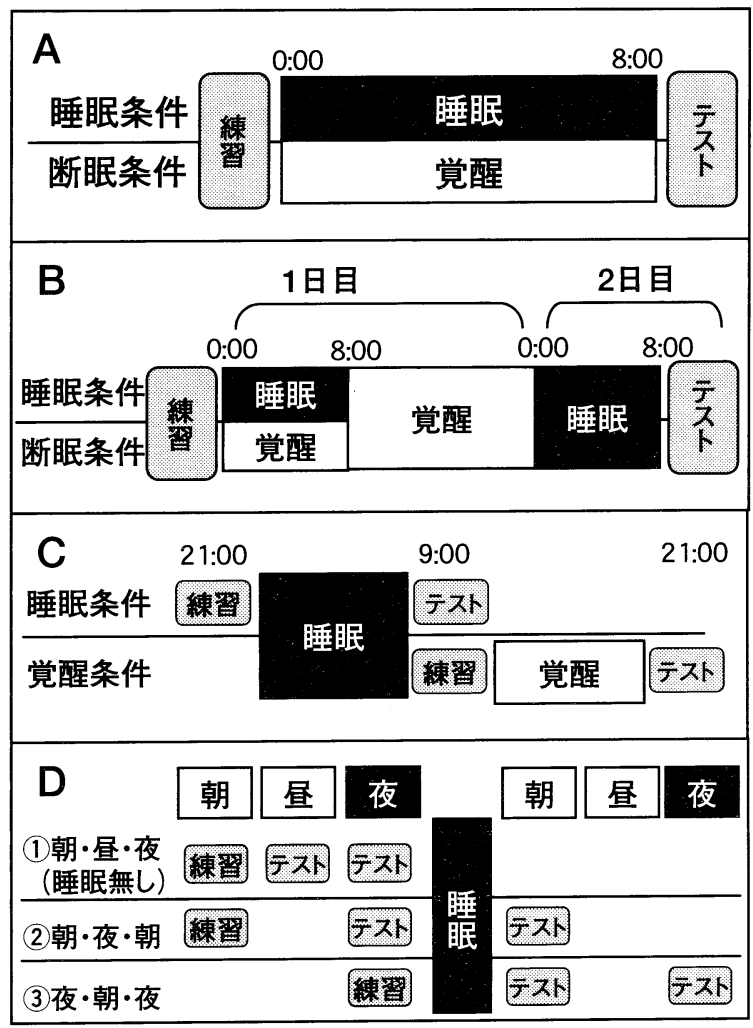

Figure 1. 睡眠条件と覚醒条件で記憶向上を比較する 実験プロトコルの例

A：課題練習後に，睡眠，もしくは断眠条件で一定 時間過ごす。テスト時に睡眠条件と覚醒条件の成 績を比較する。覚醒条件時の疲労・眠気・ストレ スの影響が交絡要因となる。

B : 断眠条件は 1-2 夜の回復睡眠後にテストを行う ことにより, 疲労・断眠・ストレスの影響を除外 する。この図では 1 夜の回復睡眠後にテストを行つ ている。断眠条件の睡眠構造が睡眠条件とは異な る可能性, 課題によっては両条件ともに向上が見 られない可能性も考えられる。

$\mathrm{C}$ ：睡眠を取ったときの記憶向上量と, 同時間の覚 醒時における向上量を比較する。練習時の課題成 績に差がないことが前提条件となる。覚醒条件に おける覚醒中の活動が交絡要因となる。

$\mathrm{D}: 3$ 条件間で成績の向上を比較する。順序効果と 睡眠の影響を分離して分析することが可能である。 日中の成績向上量よりも睡眠後の向上量が大きけ れば睡眠による効果を示すことができる。
て課題練習時の成績に違いがないことの確認, 昼間の 活動による干渉効果の統制が必要である。

(2) 特定の睡眠状態の影響を検討

(a) REM・NREM 断眠 : REM 睡眠，NREM 睡眠どちら かが出現する度に被験者を覚醒させ, 対象とする睡眠 状態のみを遮断する方法である（Figure 2A）。条件間

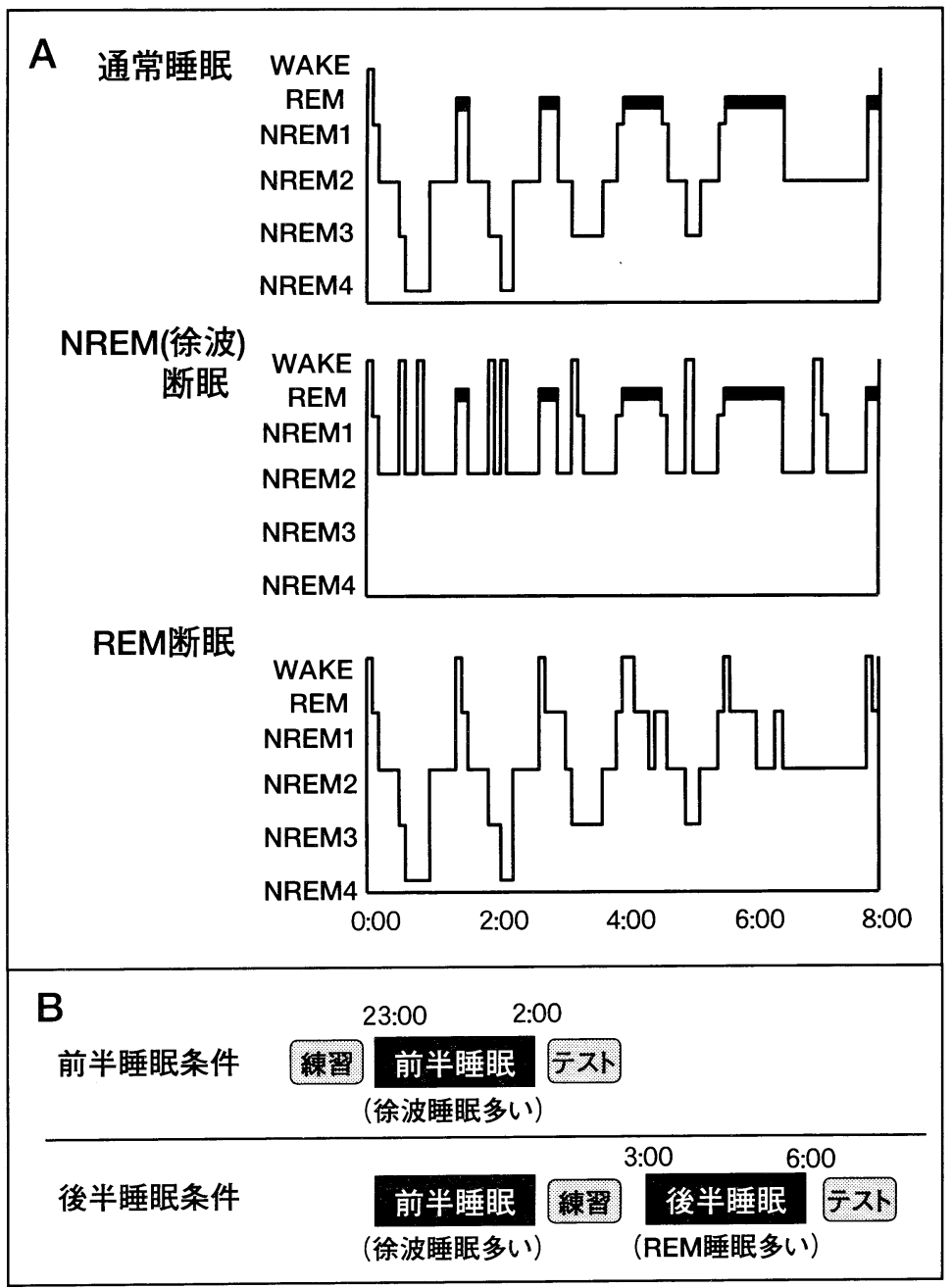

Figure 2. 睡眠内容と記憶向上量の関係を検討する実 験プロトコルの例

A : NREM( 徐波) 断眠 - REM 断眠の例。断眠の対 象とする睡眠段階が出現したときに被験者を強制的 に覚醒させ，NREM， REM 睡眠を部分的に遮断する。 強制覚醒によるストレスの影響が問題となる。深い NREM 睡眠 (徐波睡眠) を対象にすると前半に, REM 睡眠なら後半に覚醒させる回数が増えるため, ストレスを与えた時間帯による影響も交絡要因とな りうる。

$\mathrm{B}$ ：前半・後半睡眠の例。前半睡眠では徐波睡眠が 多く出現し, 後半睡眠は REM 睡眠が多く出現する。 それぞれの睡眠の前後に課題を行い, 徐波睡眠・ REM 睡眠のどちらが記憶に関わつているか検討する。 練習の時間帯が異なるので, 練習時点で成績の差が 無いことが前提となる。 
で成績を比較することによって，その睡眠状態が記憶 に与える影響を検討することができる。REM， NREM 断眠条件間で, 覚醒回数, 断眠の対象以外の 睡眠変数をそろえる必要がある。また, 睡眠中繰り返 し強制的に覚醒させられることはそれ自体がストレス となり，特定の睡眠段階が奪われたことによる効果な のか，ストレスによる影響なのか区別できないという 問題点がある。さらに深い NREM 睡眠は睡眠前半に, REM 睡眠は睡眠後半に多く出現するため, ストレス を与えられた時間帯という交絡要因が加わることも考 慮しなくてはならない。

(b) 前半睡眠, 後半睡眠の比較: 深い NREM 睡眠が多 く含まれる前半睡眠の前後に課題を行う条件と, REM 睡眠が多く含まれる後半睡眠の前後に課題を行 う条件を比較する（Figure 2B）。被験者を繰り返し覚 醒させることなく深いNREM 睡眠, REM 睡眠の効果 を検討することができる。課題を行う時間帯による影 響が無いことを検証する必要がある。例えば, 後半睡 眠条件では前半睡眠後に覚醒して課題を行うので, 眠 気など身体的・心理的状態が前半睡眠条件と異なるお それがある。

(c) 睡眠内容の検討 : 課題を行った後の睡眠内容に対 し視察による睡眠段階判定, またはコンピュータによ る脳波の定量的解析等を行い, 睡眠後の成績向上量と 得られた睡眠変数との関係を検討する方法である。学 習後と学習なしのコントロール条件後の睡眠状態の比 較を行い, 学習によって REM, NREM どちらの睡眠 が増加したかを検討することもある。近年では PET など脳イメージングを用いた検討も行われている。コ ントロール条件との比較を行っていない場合, 睡眠内 容の変化により課題成績が向上したのか, 睡眠パタン, 課題成績の個人差に見かけ上の関係が生じたのか判断 できないという問題点がある。さらにコントロール条 件との比較を行ったとしても, 記憶課題を行ったとき 之同様の身体的, 精神的負荷をかけ, しかも学習効果 を伴わない統制課題を行わないと, 学習による変化で あるのか, 課題による負荷, ストレスによる変化であ るのか区別できないという問題点もある。

\section{2 記憶の分類一手続き記憶と宣言的記憶}

睡眠と記憶の関係を考える際に重要なのは記憶の分 類である。これまでに脳損傷患者の研究や様々な記憶
テストを用いた研究により, 記憶は宣言的記憶と手続 き記憶に分類できることが知られている。宣言的記憶 とは, 言葉やイメージで表せる記憶であり, 英単語の 意味・緅り, 両親の名前, 電話番号の記憶などが挙げ られる。一方手続き記憶とは技能の習得に関連する言 葉では言い表すことのできない記憶である。楽器の演 奏, 車の運転, スポーツ時の身体の動き, 物体の特徵 の見極めなどがある。記憶を想起するという意識が働 かないのも特徵の一つである。この二つの記憶は異な る脳内機序によって行われていることから, 睡眠中の 脳活動と記憶に関して検討する場合, どちらのタイプ の記憶を対象としているかが重要となる。

しかし，実際に普段我々が用いている記憶は宣言的 記憶と手続き記憶の成分が混在しており, 厳密にはど ちらか一方の記憶のみを用いていることはまれである。 例えば英単語の綴りを覚えるときにはアルファベット の順序を覚える必要があり,これは宣言的記憶である。 しかし, 何度も繰り返し書き取ることで暗記すると, テストで思い出すときに, 頭で考えても思い出せなか つた綴りを自然と書き取れることがある。これは手続 き記憶が働いた例であろう。さらに英単語を発音して 覚えたならば，喉や舌の動きといつた手続き記憶が関 わってくる。このように記憶を手続き記憶と宣言的記 憶に分類することには問題点もあるが, 記憶を一様に 扱うのではなく種類別に分類して実験を行うことによ って, 特定の種類の記憶向上が睡眠に依存して起こる ことが分かってきている。以下にそれぞれの記憶夕イ プと睡眠との関係について，これまで得られている知 見を述べる。

\section{3 手続き記憶}

\section{(1) 視覚弁別能力}

1994 年に Karni, Tanne, Rubenstein, Askenasy, \& Sagi (1994) によって視覚刺激の特徴検出成績が睡眠後に向 上することが報告された。この報告により，睡眠が記 憶にとって休息以上の効果, すなわち向上をもたらす として, 睡眠と記憶研究に関する研究が見直されるき つかけとなった。現在までに最も多くの実験的手法を 用いて睡眠後に成績の向上が起こることが確かめられ ている課題である。従来, 宣言的記憶課題においては どれだけ忘れないでいられるか，という引き算勘定で しか睡眠の記憶への効果を表せなかったのに対し, 手 
続き記憶課題を用いることにより睡眠後に起こる成績 の向上を示すことが可能となり，睡眠および記憶研究 者に大きなインパクトを与えたものと考えられる。

視覚弁別課題は，パソコンの画面上に一瞬だけ提示 される図版の特徵を読み取る課題である（Figure 3）。 図版はポップアウトと呼ばれる，特徴が即座に目に飛 び込んで見える現象を引き起こす。被験者は画面中心 の注視点を見つめ, 画面中心部と周辺視野に呈示され る特徵を同時に検出する。その直後にマスク刺激と呼 ばれる妨害刺激が呈示されるが，弁別能力が向上する と，マスク刺激が呈示されるまでの間隔（刺激間間隔） が短くても特徵を読み取れるようになる。刺激間間隔 を徐々に短縮し， $80 \%$ の弁別が維持できた間隔が成績 となり, 再テスト後の刺激間間隔の減少量が向上量と なる。以下にこの課題を用いて記憶向上と睡眠の関係 を調べた研究をいくつか紹介する。

Karni et al. (1994) はこの課題の練習後, 通常睡眠お よび，REM 睡眠のみを遮断するREM 断眠と深い NREM 睡眠（徐波睡眠）を遮断する徐波断眠を行つ た（Figure 2A）。その結果，通常睡眠後と徐波断眠条 件後では成績が向上したのに対し（通常睡眠：23 ms, 徐波断眠：19 ms), REM 断眠条件では向上しなかつ た (0 ms)。そのため Karni et al. (1994) は，この手続き 記憶の向上には練習後の REM 睡眠が不可欠であると 考えた。

Gais, Plihal, Wagner, \& Born (2000)は, 徐波断眠, REM 断眠に伴うストレスの影響を除外するために,
睡眠時間を前半 (22:30-01:30) と後半 (04:00-07:00) に分 け，それぞれの睡眠前後に課題を行い，睡眠後の成績 を比較した（Figure 2B）。その結果，有意な向上は徐 波睡眠が多く含まれる前半睡眠後にのみ起こった。睡 眠前の成績は両条件間に差がみられなかった。そのた め彼らは学習後の徐波睡眠が向上に不可欠であると考 えた。この結果は徐波断眠を行っても向上が起こった Karni et al. (1994)の結果とは異なる。徐波断眠条件に おいて完全に遮断しきれなかった徐波睡眠（Karni et al. (1994) の徐波断眠条件では約 30 分の徐波睡眠が出 現している）が向上を起こしたという可能性も考えら れるが,この不一致の原因ははっきりしていない。

断眠や短時間睡眠による睡眠不足が成績向上を妨げ た可能性もある。この疑問に答えるために Stickgold, James, \& Hobson (2000) は課題後に睡眠を取る条件と 断眠条件で三日後の成績を比較した（Figure 1B）。断 眠条件で眠気が蓄積している翌日ではなく，回復睡眠 を二晚とつた後に再び課題を行うことで，断眠条件に おける眠気と疲労の影響を除去した。その結果, 練習 後に睡眠を取った群には三日後の課題成績に有意な向 上がみられたが (19.8 ms)，断眠群の向上は有意では なかった $(3.9 \mathrm{~ms}) 。 こ の$ 結果から, 練習を行ったその 日の夜に眠らないと, この手続き記憶学習は成立しな いことが示された。この結果は練習後の睡眠による成 績向上は翌日のコンディションを整える以上の効果が あり, 練習後の睡眠中に脳内で記憶向上過程が起こっ ていることを意味している。
(1)

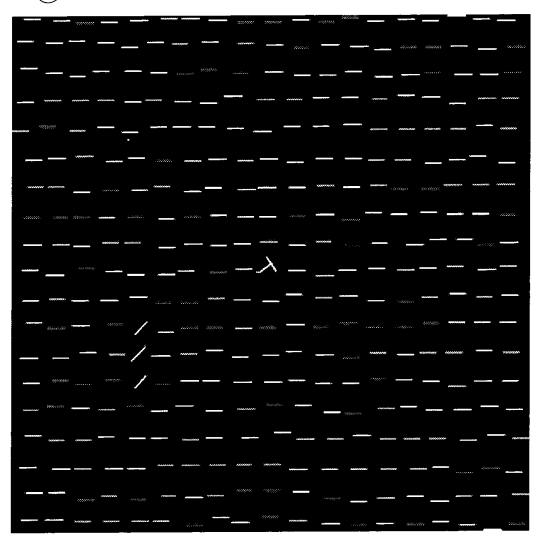

(2)

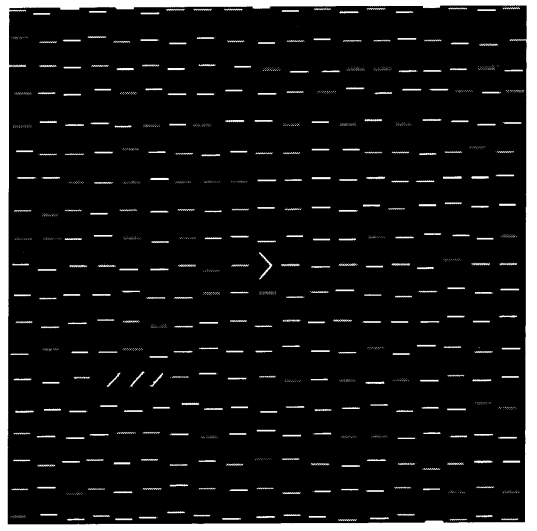

(3)

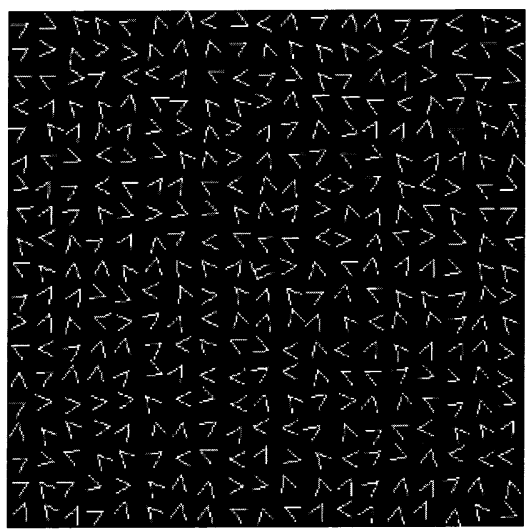

Figure 3. 視覚弁別課題の刺激例

(1)と(2)はターゲット刺激であり，画面中心部に提示される回転した文字の弁別（11) T, (2)はL）と，左

下に提示された三本の斜めの線が縦並びか, 横並びか（11は縦並び，(2)は横並び）の二つの弁別を同時 に行う。(3はマスク刺激であり，ターゲット刺激提示からマスク刺激提示までの間隔が短くなるほど難 易度が上昇する。 
Stickgold, Whidbee, Schirmer, Patel, \& Hobson (2000) は課題後被験者に自由に睡眠をとらせて, 課題後の睡 眠内容と向上量の関係を分析した。その結果, 睡眠時 間の最初の 4 分の 1 に含まれる徐波睡眠と最後の 4 分 の 1 に含まれる REM 睡眠の量を掛け合わせることに よって, 向上量を 8 割説明できることを示した。つま り前半の徐波睡眠と後半の REM 睡眠どちらが久けて も向上は起こらず, 両者が多いほど向上量が大きいと いうわけである。

Mednick, Nakayama, Cantero, Atienza, Levin, Pathak, \& Stickgold (2002) は昼寝の効果を検討した。日中繰り返 しこの課題を行うと成績が悪化していくことが示され た。この悪化は報酬による動機づけの上昇によっても 食い止めることはできず, 覚醒中の脳内過程はこの課 題の向上をもたらさないことを示した。しかし，短時 間の仮眠は成績悪化を食い止める効果があることが示 された。さらに，60 分間もしくは 90 分間と長時間の 仮眠を取つた場合，仮眠中に徐波睡眠とREM睡眠の 両方が出現したときに限って向上がみられ, その効果 は夜間睡眠時の向上量とほぼ同じであった (Mednick, Nakayama, \& Stickgold, 2003)。これらの結果は夜, 昼 に関わらず，徐波睡眠とREM 睡眠が出現する過程が 視覚弁別課題の向上に必要であることを強く示す結果 である。Gais et al. (2000)の前半睡眠の内容を検討す ると, 徐波睡眠 74 分間に対し, REM 睡眠が 24 分間含 まれていたことから，長時間の仮眠時と同様に徐波睡 眠とREM 睡眠の過程が向上を起こしたものと考えら れる。

これらの様々な実験手法を用いた検討により,この 視覚弁別能力の向上は睡眠依存性の現象であることが 確かめられている。

\section{(2) 手指運動技能}

ピアノ, ギターの演奏時やタイピングで行うような 手指の運動学習にも睡眠の効果が認められている。こ の技能も様々な実験方法を用いて睡眠が向上にもたら す影響についての検討が行われ, 覚醒中にも成績は向 上するが，より大きな向上は睡眠後に起こることが明 らかになっている。

Walker, Brakefield, Morgan, Hobson, \& Stickgold (2002) はパソコンのキーボードを用いたタイピング課 題を，1）朝・昼・夕・夜 (睡眠無し), 2) 朝・夜・朝,

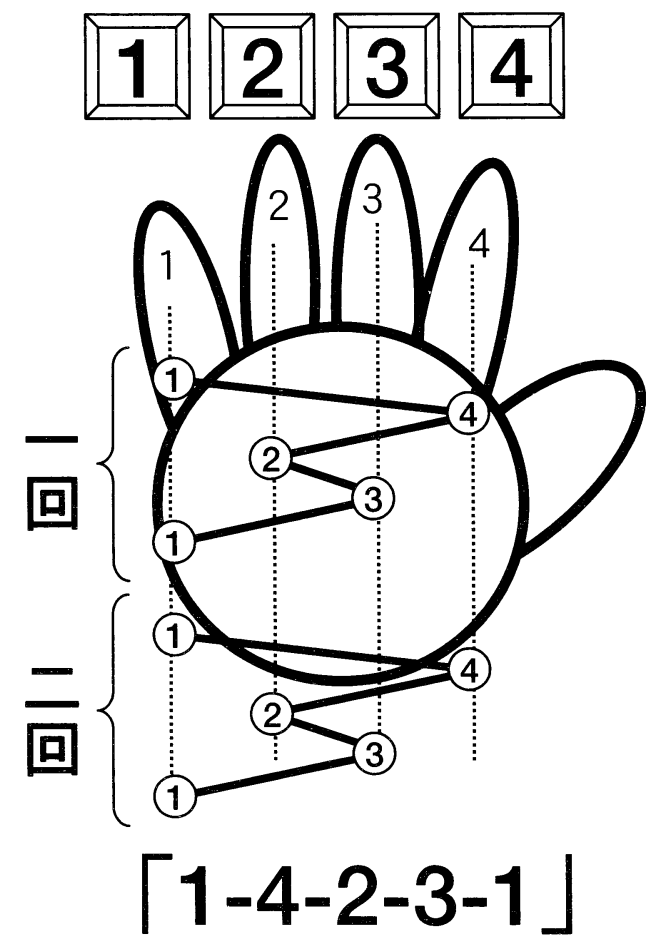

Figure 4. タイピングタスクの例 小指から人差し指が 1 から 4 の数字キーに対応して いる。提示された数字の列をできるだけ速く正確に タイプすることを繰り返す。指定時間内にタイプで きた回数，ミスの数を成績とする。

3) 夜・朝・夜の 3 条件で行った（Figure 1D の応用例）。 タイピング課題は特定のパタン（Figure 4）を一定時 間（30 秒間等）に何回吒くことができるか，もしく は一回のパタンに要する時間が成績となる。この課題 では視覚弁別課題とは異なり睡眠無し条件においても 向上が認められた（再テスト毎に 1.08 回の増加）。し かし, 睡眠後にみられる向上は日中でみられる以上で あることが示された。朝・夜・朝条件では朝から夜に かけて 3.9\%（0.94回）の向上だったのに対し，夜か ら朝の睡眠後では $18.9 \%$ （4.33 回）であり, 夜・朝・ 夜条件でも夜から朝の睡眠後には $20.5 \%$ （4.50 回）の 向上がみられたが，その後覚醒をはさんだ朝から夜の 向上は $2.0 \%(0.53$ 回）であった。彼らは日中の向上 量が少ないのは課題以外に日常生活で行う手指の運動 による干渉効果によるものかもしれないと考え, グロ 一ブをつけて手指の動きを統制した。この条件でも睡 眠後の向上が日中より大きいことが確認されたことか ら（睡眠後：19.7\%, 覚醒後：4.3\%), 昼間の活動に よる干渉の影響は小さく, 睡眠中の情報処理により向 
鈴木：睡眠中の情報処理

上が起こっているものと考えられた。

断眠直後の眠気を取り除く方法（Figure 1B）でも 睡眠の効果が確認されている (Fischer, Nitschke, Melchert, Erdmann, \& Born, 2005)。練習後に睡眠をと つた群では翌々日に $15.6 \%$ の向上を示したのに対し， 断眠群では $5.9 \%$ と有意な向上が認められなかった。 この結果は練習したその夜の睡眠により，手指運動能 力が向上することを示唆している。

Kuriyama, Stickgold, \& Walker (2004) は, 片手でタイ

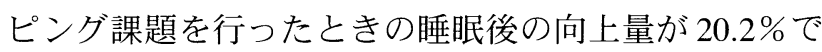
あったのに対し，両手で行うタイピング課題では 28.9 \%の向上がみられたことから，両手を用いた方が睡眠 による向上効果は大きいことを示した。この結果は, 昼間行う課題はより多くの運動野の皮質領域を使うほ ど睡眠による向上が大きいことを示している。REM・ NREM 睡眠出現量の影響については，NREM 睡眠段 階 2 の出現量, 特に後半の出現量と向上量の相関が高 いことから，中程度の深さの NREM 睡眠が向上と関 係していると考えられている (Walker et al., 2002)。

さらに複雑な手指運動の向上に及ぼす睡眠の効果も 検討が行われている。指は左右対称であるため, ピア ノでド・レ・ミと弾くときには右手と左手では用いる 指が異なる。Cohen, Pascual-Leone, Press, \& Robertson (2005) はピアノ演奏のように手指運動パタンの途中か ら手を入れ替える課題を用いて睡眠の効果を検討し ている。彼らは目的型 (goal configuration) と運動型 (movement configuration)の二種類の課題を用いた。目 的型では手を入れ替えて同じキーを吒く。すなわち指 の動きは右手と左手で異なる。例えば左から 1，2，3， 4 と並んだキーを 1 から 4 まで右手で吒くときは人差 し指 - 中指 - 薬指 - 小指の順だが, 左手に入れ替えた ときは小指 - 薬指 - 中指 - 人差し指となる。運動型で は右手と左手で同じ運指パタン（鏡映イメージ）とな り，実際に吅くキーは異なる。右手で人差し指から小 指までを使って 1，2，3，4のキーを吒いたら，左手 も人差し指から小指までを使って $4 ， 3 ， 2 ， 1$ のキー を叮く。この 2 種類の学習を朝一夜 (覚醒条件), も しくは夜一朝（睡眠条件：Figure 1C）に行った結果， 運動型課題は覚醒条件で（1 回のパタンあたり $21 \mathrm{~ms}$ の短縮)，目的型課題は睡眠条件で向上した $(35 \mathrm{~ms}$ の短縮)。この結果は，両手を組み合わせた手指運動 には2つの学習過程があることを示している。睡眠中
に起こる向上は運動型課題における運動野の処理では なく, 目的型課題における空間的な要素を含んだ処理 に対して行われることを示唆している。

(3) 聴覚, 空間・位置学習

聴覚，空間・位置学習などの手続き記憶課題におい ても睡眠後の向上が示されている。しかし，報告によ り結果が一致しないことや，異なる実験方法による結 果の確認が行われていないため, これらの課題成績の 向上が睡眠中の脳活動により起こっているのか今後の 検討が必要である。

(a) 聴覚弁別 : Gaab, Paetzold, Becker, Walker, \& Schlaug (2004) は音程のずれを聞き分ける音楽的能力が睡眠に より向上するのか, 微妙な音程の違いを聞き分ける課 題を用いて検討した。課題を行う順序を朝・夜・朝に した群と, 夜・朝・夜の群（Figure 1D，(2)，(3)）で 成績を比較した結果, 朝から夜の覚醒後に起こる弁別 正答率の向上は両条件それぞれ約 $2 \%$ と $-2 \%$ で有意で はなかったのに対し，夜から朝にかけてはそれぞれ約 $12 \%$ と $6 \%$ と両群ともに有意な向上がみられた。

Atienza, Cantero, \& Stickgold (2004)は, 複雑な音声 パタンを弁別する課題を行つた後, 睡眠条件と断眠条 件での成績を検討した。その結果，睡眠条件だけでな く断眠条件でも向上がみられ，学習後の睡眠効果は認 められなかった。しかし睡眠条件では，音声パタンに 対する事象関連電位成分 (mismuch negativity, P3a) が 48, 72 時間後に増加することが認められた。この結果は, 練習後に睡眠をとることは，行動指標に成績向上がみ られなくても，その後に起こる脳内の変化を促進する 効果があることを示唆している。

発音を聞き分ける日常的な聴覚弁別能力についても 検討が行われている。Fenn, Nusbaum, \& Margoliash (2003) はコンピュータが発生した単語の音声を識別す る課題を用いて睡眠の効果を検討した。朝練習し覚醒 を維持して夜テストと, 夜練習し睡眠をとってから朝 テストの 2 条件間（Figure 1C）で向上率を比較すると, 朝から夜の覚醒条件で 10.1 ポイントの向上, 夜から 朝の睡眠条件で 18.7 ポイントの向上と, 睡眠をとつ た後の向上率が大きいことが示された。この課題では 練習とテストで用いた単語は，同じ音素を用いた別の 単語であることから，学習効果が般化していると言う 点で興味深い。しかし，練習後に時間間隔を置かずに 
再テストを行った統制群にも向上がみられ, 睡眠条件 と向上率に差がみられないことから, 睡眠の効果は向 上というょりも低下を抑えたというのが妥当であろう。

(b) 連続反応時間課題： Maquet, Laureys, Peigneux, Fuchs, Petiau, Phillips, Aerts, Del Fiore, Degueldre, Meulemans, Luxen, Franck, Van Der Linden, Smith, \& Cleeremans (2000) は, 画面上に連続的に指示される位 置と対応したボタンを押す連続反応時間課題 (serial reaction time task: Figure 5)を行つた結果, 睡眠前に行 つた 2 回のセッションの反応時間よりも (568 ms, $533 \mathrm{~ms})$, 睡眠後のセッションで成績が向上 (444 ms) した。課 題中とその後の睡眠中の脳活動が positron emission tomography (PET)により調べられ, 練習を行った群で は練習をしなかった群と比べ, 課題中に活性化した脳 部位がその後の REM 睡眠中に再活性化することが示 された。
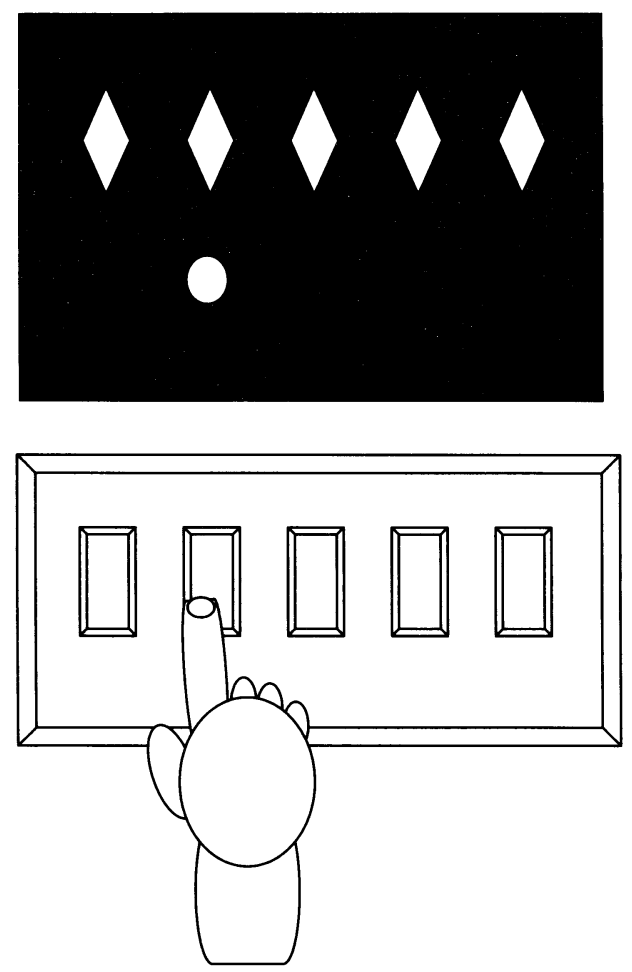

Figure 5. 連続反応時間課題の例

5個並んだボタンに対応して, 画面に菱形が提示さ れている。いずれかの菱形の下に○が提示され， 対応するボタンを押すと違う位置に○が提示される。 対応するボタンを押すことを連続して行う。○の 移動パタンにはランダム条件と, 法則性を持った 条件がある。移動パタンの法則性を学習すると反 応時間の短縮が見られる。
この選択反応時間課題はランダムに移動する移動パ タンを用いているが, 移動パタンに法則性を持たせた 場合，睡眠後に法則性に気づくか検討が行われた。 Peigneux, Laureys, Fuchs, Destrebecqz, Collette, Delbeuck, Phillips, Aerts, Del Fiore, Degueldre, Luxen, Cleeremans, \& Maquet (2003) は法則性の有るパタンと ランダムパタンの 2 種類の連続反応時間課題を行い, 睡眠後に再びテストを行った。睡眠中の脳活動をPET により測定し，成績との関係を見たところ，睡眠前の 課題においてランダムパタンよりも法則性の有るパタ ンでの反応時間が短縮した被験者ほど, 後頭葉の楔部 (cuneus) の活動が REM 睡眠中に上昇したことを示した。 法則性への気づきが顕在的か潜在的か確かめるために 次の移動位置を強制的に予測させる課題を行うと, 成 績はチャンスレベルであった。よって，法則性パタン における反応時間の短縮は潜在的な学習であることが 分かった。このことから, 無意識的な学習の向上が, その後の睡眠中に起こる特定部位の脳活動の活性化を 起こす可能性が示された。しかし, 潜在的な学習の量 （ランダムパタン課題成績一法則パタン課題成績）に は睡眠前と睡眠後で差がみられなかったことから，睡 眠後に潜在的な空間学習の向上が起こることは示され なかった。

Fischer, Drosopoulos, Tsen, \& Born (2006) も, Peigneux et al. (2003) と同様の課題を用いて睡眠が潜 在的学習に及ぼす影響を検討している。彼らは，夜練 習し睡眠後の朝にテストする条件と, 朝練習し覚醒を 維持して夜テストする条件を比較している (Figure 1C)。 両条件ともに, 法則性課題の反応時間はランダム課題 よりも短縮していたが，向上はみられなかつた。一方 強制予測課題による顕在的な学習効果を調べると, 睡 眠をとつた場合のみ正答率が $52.1 \%$ から $68.6 \%$ 向上 し，顕在的な空間位置学習に睡眠が関与している可能 性が示された。これらの結果から, 空間位置学習には 潜在的，顕在的な側面があることが分かるが，睡眠が それらにどのような効果があるのかまだ明確ではない。

(4) 洞察, ひらめき

練習によって段階的に上達していく学習ではなく, 多くの情報や選択肢の中から突然問題の解決方法がひ らめくことを洞察 (insight) と呼ぶ。この洞察も睡眠を 取ることによって起こるという報告がある。Wagner, 
Gais, Haider, Verleger, \& Born (2004) は，数字合わせ課 題を用いて睡眠が洞察をもたらすか検討した。この課 題は呈示された数に対して適切な数字を組み合わせる 試行を連続して行うが，数字の組み合わせには隠され たルールが存在し，そのルールに気づくと課題遂行時 間に大幅な減少がみられ，洞察が起こったことが確 認できる。練習後夜間に睡眠をとる条件と断眠条件 (Figure 1A)，さらに朝練習を行い，昼間の覚醒条件 （Figure 1C）において再テスト中に洞察が起こった被 験者の割合を比較した。その結果，睡眠条件以外の条 件で洞察が起こった被験者の割合は 20-25\%であった のに対し，睡眠条件では $59.1 \%$ と 2 倍以上であった。 このような統合的な問題処理能力も睡眠によって活性 化されることから，日常生活における諸問題の解決に も睡眠は効果的であると考えられる。

\section{4 宣言的記憶と睡眠}

宣言的記憶は，人の名前と顔を一致させたり，英単 語を暗記したりなど，我々が普段意識して使う言語， イメージの記憶である。近年, 手続き記憶に続いて, 宣言的記憶に関しても睡眠依存の向上が起こっている という報告が得られている。無意味綴りの暗記や対連 合学習を用いて宣言的記憶と睡眠の関係を調べた研究 は古くから行われ，前述のようにJenkins \& Dallenbach (1924) は無意味綴りを記銘した後，覚醒を維持する条 件と睡眠をとる条件でその後の再生率を比較している。 彼らはエビングハウスが示した無意味綴り記憶が失わ れていく過程（エビングハウスの保持曲線）に対して, 睡眠が記憶の保持にどのような影響を与えるのか実験 的に検証した。その結果, 睡眠条件では 8 時間後も約 半分の綴りを再生できたのに対し，覚醒条件では 1 割 程度の再生率であつた。この結果はわずか 2 名の被験 者からのデータではあるが，暗記した後は眠った方が 良く思い出すことができることを示し，睡眠中に宣言 的記憶の固定が行われていることを示唆している。し かし，この実験結果は，覚醒維持によって起こる情報 の入力がもたらす干渉効果を防いだだけであるとも考 えられ，睡眠自体に宣言的記憶を強化する役割がある と結論づけることはできない。

Benson \& Feinberg (1975)は 12 項目の無意味綴りを 用いて朝学習条件と夜学習条件で, 8 時間後と 24 時 間後の再生率を比較している。朝学習条件では睡眠を
とるのは約 16 時間後だが, 夜学習条件では直後に睡 眠をとることになる。 8 時間後の再生数は夜学習条件 で 11.00 だつたのに対して，朝学習条件では 7.83 であ り，直後に睡眠をとることが効果的であることを示し ている。両条件とも睡眠をとった後となる 24 時間後 の再生数は夜学習, 朝学習ともに 9.67 であった。す なわち, 夜学習条件では再生数が 8 時間後よりも 24 時間後で減少したのに対し，朝学習では 24 時間後の 再生数が増加した。この結果は被験者の記銘時の学習 効率をそろえても同様であり，学習能力の影響ではな く，宣言的記憶は学習するのが朝であっても夜であっ ても睡眠後に固定されることを示唆している。

Benson \& Feinberg (1977) は対連合課題を用いた検討 も行っている。関連の無い16 単語対を用いて直後に 睡眠をとる夜学習と朝学習において $8,16 ， 24$ 時間後 の再生数を検討した。直後に睡眠をとつた夜学習条件 の再生数は, 記銘直後の再生と比べて $+0.30,-1.00$, -0.70 と安定していたのに対し, 学習後約 16 時間覚醒 を維持する朝学習条件では，-3.20，-1.80，-3.00 と減 少を示した。この結果は学習直後に眠ることが記憶の 保持に有効であることを示している。しかし，この結 果は睡眠中に記憶が向上したと言うよりも，睡眠によ り学習後の干渉を防いだと考えるのが適当である。

宣言的記憶は記銘直後に再生率が高く, 時間経過に より低下することから，睡眠によって再生率の低下を 抑えることは報告されてきたが，再生率が増加するこ とを示すのは困難であった。しかし，近年睡眠後に宣 言的記憶の再生率が向上することが示されている。

Plihal \& Born (1997) は睡眠状態が宣言的記憶に及ぼ す影響を検討するために，24 項目の対連合学習と前半・ 後半睡眠の方法により検討を行った（図 2B)。徐波睡 眠が多い前半睡眠条件では再生単語数が 17.6 から 23.3 と有意に増加し, REM 睡眠の多い後半睡眠条件, 同時間に行った覚醒維持条件では増加がみられなかっ た。この結果は,これまでの研究とは異なり, 睡眠前 よりも睡眠後で思い出すことのできる単語数が増加す ることを示した点で重要である。

Gais, Molle, Helms, \& Born (2002) は 168 単語対を学 習する課題後と, 同じ単語を呈示しアルファベットの 形態に曲線が含まれているか判断する統制課題後の睡 眠を比較し, 宣言的記憶学習後に起こる睡眠の変化を 検討した。睡眠段階出現量には両条件間に差がみられ 
なかつたが, NREM睡眠段階 2 における睡眠紡鍾波の 密度が対連合課題群で有意に増加することを示した。 この結果から彼らは宣言的記憶の処理には睡眠紡錘波 が関係していると推測している。しかし, 睡眠前と比 べて睡眠後にどの程度の課題成績が向上したのかは確 かめられていないため, 宣言的記憶の向上と睡眠紡錘 波の活動が関係しているかは定かではない。

Schabus, Gruber, Parapatics, Sauter, Klosch, Anderer, Klimesch, Saletu, \& Zeitlhofer (2004) は夜間睡眠後の対 連合学習課題の成績向上量と NREM 睡眠段階 2 のス ピンドル活動量の増加が正の相関を示すことを報告し, 睡眠紡鍾波が宣言的記憶の向上に与える重要性を強調 した。しかし, 彼らの結果も睡眠後の再生率の増加は 有意ではないため(睡眠前：62.64\%, 睡眠後 : 63.70\%, $p=.054)$, 宣言的記憶の向上が睡眠依存特に睡眠紡錘 波との関係については更に検討する必要がある。

暗記した内容を眠っている間により強固なものにで きないか, という願いは試験前の学生でなくとも考え ることであろう。近年そんな願いが叶う可能性が示さ れている。Marshall, Helgadottir, Molle, \& Born (2006) は 対連合学習課題後の睡眠中に Transcranial direct current stimulation (tDCS: 経頭蓋直流刺激) を行い, 睡眠前半 の NREM 中に, 睡眠徐波と同様の周波数である $0.75 \mathrm{~Hz}$ の徐振動電位を約 30 分間流し, 睡眠徐波を増 幅させた。プラセボ刺激において睡眠後は 2.08 個再 生語数が増加したのに対し, 刺激後は 4.77 個の増加と, プラセボ刺激と比べ有意な向上を示した。この結果は, 宣言的記憶の向上には，睡眠紡錘波よりも徐波睡眠が 重要であることを強く示しているが, tDCS は睡眠紡 鍾波も増幅していたことから，宣言的記憶に寄与して いるのが睡眠紡錘波であるか睡眠徐波であるかは今後 まだ検討の余地がある。tDCS は無痛性, 非侵襲的な 手法ではあるが, 自然発生的な睡眠脳波を変化させる ためその適用は慎重であるべきである。しかし，その 効果がより明確になれば, 記憶に関する幅広い分野で の応用が可能であることから今後の研究の進展が期待 される。

上記に記したように, Plihal \& Born (1997) 以降, 宣 言的記憶が睡眠によって向上することを示した研究が いくつか報告されているが, 注意しなければならない のは, それらの研究は全て関連語による単語対リスト を用いているという点である。Plihal \& Born (1997)の
使用した単語対は動物一犬, 鳥一熟といったカテゴリ 一に対してその例を答えるという比較的記銘が容易な ものであり，新しい連合記憶を記銘すると言うよりは すでに長期記憶に保持されている連合記憶を再認する 課題とも考えられる。Schabus et al. (2004)が使用した 対単語は, 「家族一結婚」,「新聞一インタビュー」,「母 一子」と単語間に強い関連を持ったものである。 Marshall et al. (2006)が用いた対単語も Plihal \& Born (1997) と同一のものである。これらの課題は我々が日 常的に行う英単語の意味や綴りを覚える, 初対面の人 の名前を覚えるといったことと比べると容易であり, 異なるタイプの学習であるとも考えられる。初めて覚 える宣言的記憶が海馬に強く依存するのに対し, 関連 のある対単語の学習はすでに脳内に存在する記憶情報 に依存し, 海馬依存の学習ではないと考えられる (Stickgold, 2004)。よって, テスト前の一夜漬けで暗記 するような初めて覚える宣言的記憶は睡眠と関係しな い可能性もある。この理由から, 宣言的記憶と睡眠の 関係については, 使用する課題, 睡眠条件などの実験 方法など様々な側面から知見を重ねていく必要がある。

\section{3 睡眠中の情報出力一夢見体験に現れる記憶}

睡眠中にも夢見体験という形で記憶の出力は行われ る。夢見体験は覚醒時に入力された情報が形を変えて 再生されたものと考えることができる。

\section{1 夢はいつ起こるか}

\section{(1)REM, NREM 睡眠}

従来, 睡眠中の情報出力, すなわち夢見体験は REM 睡眠中にのみ起こると考えられてきた。しかし 近年, 夢見体験は REM 睡眠中だけではなく, NREM 睡眠中にも起こることが明らかになっている (Nielsen, 2004; 鈴木 - 久我・内山, 2002; Takeuchi, Miyasita, Inugami, \& Yamamoto, 2001)。

従来, REM, NREM 睡眠から覚醒させて夢報告を得 るだけでは, 報告された夢見体験が本当に目覚める直 前の REM, NREM 睡眠中に起こつたのか, それ以前の NREM, REM睡眠中に起こつたものであるのか判断す ることができなかった。近年, この問題を克服するた めに新しい方法を用いて REM, NREM 睡眠中の夢見体 験の特徽を明らかにしようとする研究が行われている。

Takeuchi et al. (2001) は, 夜中に一旦起床させた被験 
者を REM 睡眠出現周期に合わせて再び就床させるこ とで入眠時 REM 睡眠を誘発させる手法を用いた。こ の方法により REM 睡眠の前に含まれる NREM 睡眠の 影響を除外した。5 分間の REM 睡眠と NREM 睡眠後 に得られた夢見体験を比較すると，REM 睡眠では 76.4\%，NREM 睡眠では $12.3 \%$ の夢報告が得られた。

鈴木他 (2002) は 20 分間の睡眠区間と 40 分間の覚醒 区間を 78 時間連続して施行し，REM睡眠が含まれた 睡眠区間 (REM nap) と NREM 睡眠のみの睡眠区間 (NREM nap) 後の夢見体験を比較した。その結果 REM nap $71.2 \%$, NREM nap で $17.9 \%$ の夢見体験が報告 された。

これらの厳密に統制された害験により，REM睡眠 時に高い確率で夢見体験が起こっていること，その一 方で NREM 睡眠中にも 1 割から 2 割の確率で夢見体 験が起こることが確認された。

(2) 睡眠経過・生体リズム

夢見体験の出現には，REM, NREM 睡眠だけでなく, 睡眠経過，日内変動という要因も重要であることが示 されている。

Fosse, Stickgold, \& Hobson (2004)は, REM, NREM 睡眠からの覚醒時に精神活動を報告させ，その内容の 違いを検討している。第3 者がそれらの報告を分析し た結果，REM 覚醒の報告は夜間を通じて幻覚的 (hallunating)であるのに対し，NREM 覚醒では睡眠の 経過とともに幻覚的内容が増加した。一方, 思考と判 定された報告はREM覚醒時には一貫して少なかったが, NREM 覚醒時には夜の前半で多く, 後半に減少した。 この結果から NREM 睡眠時の精神活動は朝方になる につれて奇妙な内容になることが分かる。さらに， Stickgold, Malia, Fosse, Propper, \& Hobson (2001) は精神 活動報告時の単語数を分析した結果, NREM 睡眠か ら目覚めたときの報告単語数は睡眠経過に従って長く なることを示した。

Suzuki, Uchiyama, Tagaya, Ozaki, Kuriyama, Aritake, Shibui, Tan, Kamei, \& Kuga (2004) は, 前述の 20 分間の 睡眠と 40 分間の覚醒を繰り返す方法により, 夢見体 験の出現量に日内変動があることを示した。生体リズ ムの個人差を考慮して, メラトニン分泌開始時刻を午 後 10 時として被験者のデー夕を標準化すると, 夢見 体験量は朝 8-9 時をピークとする変動を示すことが分
かった。この夢見体験量のピークはREM nap では顕 著でなく, NREM napにおいて明確であった。この結 果から，REM 睡眠時の夢見体験量は常に多いが, NREM 睡眠時の夢見体験は朝方をピークとする日内 変動を示すことが明らかになった。

\section{2 夢に出力される記憶一エピソード記憶, 意味記憶}

夢に現れる記憶とはどのような種類の記憶であろう か。Tulving (1972)は，記憶を特定の時間と場所が関 係し, 経験者の印象を伴うエピソード記憶と, 特定の 時間や場所に関係しない一般的な情報に関する記憶で ある意味記憶に分類している。覚醒時に入力された記 憶はまず，いつ，どこでといった内容を含んだエピソ 一ド記憶として貯蔵されるが, 時間経過とともに変化 し，いつ, ぞこでといつた時間的内容を失い，知識と しての記憶である意味記憶となる。いくつかの研究に より夢の素材として現れる記憶はエピソード記憶より も, 意味記憶が多く, それらが組み合わさることで, 夢の内容を構成していることが示されている。

Fosse, Fosse, Hobson, \& Stickgold (2003)は2 週間に わたつて 29 名の被験者に日中の活動, 出来事, 関心 と夢の内容を記録してもらい，覚醒中の出来事がどの 程度夢に組み入れられているか採点させた。得られた 299 の報告のうち，65\%は日中の経験に基づくもので あったが, 日中の出来事と同一の体験と評価された夢 報告は $1.7 \%$ (5 件) と非常に少なかつた。つまり，夢 には覚醒中に入力された経験が出力されるが, エピソ ード記憶としてそのままの形で出力されるのではなく, 素材として形を変えた意味記憶として出力されること を表している。

Cicogna, Natale, Occhionero, \& Bosinelli (2000)は REM 覚醒と NREM（徐波睡眠）覚醒の夢報告を比較し, エピソード記憶と分類されるのはREM で $38.6 \%$, NREM で 48.4\% と NREM 睡眠から覚醒したときに多 かったが，意味記憶と分類されるのはREM で $61.4 \%$, NREM で 27.8\%とREM 睡眠から覚醒したときに多か つた。この結果は，REM 睡眠中にみられる夢内容は エピソード記憶が知識化, 断片化した意味記憶が多く, NREM 睡眠中の夢内容は比較的実際のエピソードを 維持していることを示唆している。

Stickgold, Malia, Maguire, Roddenberry, \& O'Connor (2000) は覚醒中にテレビゲームを集中的に行わせ，夢 
の内容にどのような影響を及ぼすのか実験的に検討し た。彼らは 3 日間にわたり一日約 2 時間, 合計 7 時間 テトリスを行わせ, その後の入眠時に起こる心象体験 を尋ねた。テトリスを初めて行った初心者には「ブロ ックを整列させた」といつたテトリスの内容と関連し た入眠時心象が全体の報告のうち約 7\%みられた。し かし, 時間情報や実験室の様子などエピソード記憶と みられる報告をした者はいなかった。一方テトリス上 級者には, 以前行った古いバージョンのテトリスを新 しいパソコンで行う夢など, 久しぶりに行ったテトリ スが，過去に行ったテトリスの記憶を誘発するような 内容がみられた。これは目覚めているときに行われた 情報の入力は, 睡眠中にその情報と関連した過去の意 味記憶を引き起こす効果を持つことを示唆している。

覚醒時に入力された情報がそのままエピソード記憶 として夢で再現されることもある。トラウマチックな 体験に伴う悪夢などがそうである。外傷後ストレス障 害 (post-traumatic stress disorder: PTSD) 患者は, 実際に 起こったトラウマ体験を悪夢として繰り返し体験する こと, 海馬容量の減少がみられることが報告されてい る(Nielsen \& Stenstrom, 2005)。このことは, エピソー ド記憶を悪夢として繰り返し体験することは海馬機能 が関与していることを示唆している。海馬損傷患者に 夢を尋ねると単調で情動を伴わない, 実際に起こった 短いエピソードを繰り返し報告することも示されてい る (Torda, 1969)。近年の臨床研究や脸イメージ研究に よりエピソード記憶は前頭前領域や海馬領域と関連し ていることが示されていることから (Cabeza, Prince, Daselaar, Greenberg, Budde, Dolcos, LaBar, \& Rubin, 2004; Tulving, 2002), 海馬は, 覚醒時にはエピソード 記憶を作り上げ，夢ではエピソード記憶を取り除く機 能を持つのではないかと推測されている (Nielsen \& Stenstrom, 2005)。

\section{3 忘れた記憶を夢に見る?一潜在記憶と夢}

自分では見覚えのない記憶が夢に現れることもある。 この現象から, 夢に出力される記憶情報は, 体験した 出来事を思い出しているという意識を伴う顕在記憶で はなく, 想起の意識を伴わない潜在記憶であるとも考 えられる。

宮城 (1972) は, フーコー (Foucault, M) やペツル (Pötzl，O) といった 20 世紀初頭の夢研究者が, 覚醒時
に注意しなかったものが夢に現れること, 瞬間露出機 を使って絵をいくつか見せると, 瞬間露出時には気づ かなかったものが夢に現れることを報告していたと述 べている。このように潜在記憶が夢に出現することは 古くから指摘されてきたが, 方法論的な困難から実験 的な検証は少なかった。

Stickgold, et al. (2000) は両側性海馬損傷による記憶 障害を持つ患者にも前述の実験と同様にテトリスを行 わせて，入眠期の心象体験を報告させている。彼らは 宣言的・顕在的記憶に障害があるため, 実験中自分が テトリスというゲームを行った自覚は全くなかったに もかかわらず，入眠期に「上から何か落ちてきてそれ らの形をそろえようとした」というテトリスと関連す る報告をした。すなわち，自分では忘れてしまってい る記憶が，睡眠中に出力されたのである。この結果を 健常者に適用するにはまだ今後の検討が必要であるが, 夢見体験に現れる見たこともない人の顔や風景は, い つかどこかで見たにも関わらず忘れてしまった記憶が 出力されたとも考えられる。

今後, 新たな潜在記憶測定手法を適用することによ り，夢に出力される記憶の性質がさらに明らかになる と思われる。

\section{4 いつ体験したことが夢に出力されるか}

夢に出力される出来事はいつ, ぞこでといった情報 を失い, エピソード記憶から意味記憶に変化したもの が多いが，覚醒時に入力された情報が睡眠中に出力さ れるまでにはどのくらいの時間を要するのであろうか。

Jouvet (1992 北浜訳 1997) は, 自らの夢見体験の内 容と日中の出来事の関係をみると, 旅行中の出来事は 約 1 週間後に夢に現れると述べている。例えば 1 週間 の海外旅行をしたときに, 海外の初めて見た風景が夢 に現れるのは帰国してからであった。これは新しい記 憶がエピソード記憶として記銘された後に, 夢見体験 の材料となる意味記憶に変換されるまでに 1 週間程度 の期間がかかることを示唆している。

Nielsen, Kuiken, Alain, Stenstrom, \& Powell (2004)は 夢に現れる記憶には, 前日の出来事と約 1 週間の期間 をおいて現れるものの 2 種類があると報告している。 彼らは 370 名の大学生に対し，1 週間夢日記をつけさ せた。1 週間後, 最も印象深い最近の夢を選ばせ, そ の夢から1-7 日前のいずれかの日の出来事を思い出す 
よう指示された。何日前の出来事を思いだすかはラン ダムに割り当てられた。そして, 指定された日の出来 事と夢の内容がごの程度関連するかを 0-9 点で評価さ せた。その結果, 夢の内容は, 夢の前日と7 日前の出 来事との関係が強いことが示された。この方法は, 夢 の何日前の出来事との関連性を評価するかランダムに 被験者に割り当てることによって, 印象に残った特定 の日の出来事と夢の内容をこじつけて関連づけないよ う工夫が施されているため, 結果の信頼性は高いと考 えられる。しかし，この傾向がみられたのは指定され た日の出来事を高い確信を持って思い出すことのでき た被験者群に限られていたため, 潜在記憶が夢に現れ る影響についても今後検討する必要がある。

Stickgold et al. (2000)のテトリス実験でも，テトリ ス初心者の入眠時心象にテトリスが登場するのは初め てテトリスを行った晚ではなく，その約 90\%(17/19) が2夜目であることが示されている。この結果も, 新 しい体験が夢に出力されるまでには一定の時間を要す ることを示している。

動物実験ではこの現象の背景となる結果が得られて いる。入力された記憶情報の主なものは海馬から新皮 質に移転するのに約 1 週間を要することが分かってい る (Thompson, Moyer, \& Disterhoft, 1996)。入力された 情報が夢に出力されるまでの時間差は, この脳内の記 憶過程を反映しているのかもしれない。

\section{5 なぜ, 夢の内容は奇妙なのか}

夢内容の不思議さ, 奇妙さはどのようにして生じて いるのだろうか。夢見体験では意味記憶が覚醒時とは 異なる様式で組み合わされることによって特徵的な不 思議な内容が作られているという説がある。

Stickgold, Scott, Rittenhouse, \& Hobson (1999) は起床 直後に起こる睡眠慣性（覚醒しているが，睡眠状態を 引きずった状態）を利用して，REM，NREM睡眠中に
起こる意味記憶の連合様式を検討した。彼らは NREM 睡眠, REM 睡眠それぞれの状態から被験者を 覚醒させ, 直後に意味プライミング課題を行った。意 味プライミング課題は, 呈示された文字列が正しい単 語か無意味経りかを判断する語彙弁別を行わせる。判 断を行うターゲット語（「たべる」）の前に意味的に関 連がある単語を短時間 (200 ms 等) 呈示すると (例：「ご

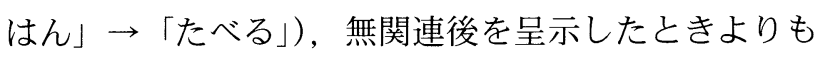

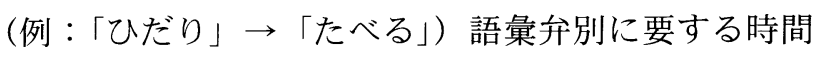
が短縮する。これは意味プライミング効果と呼ばれ， 潜在的に起こる連想の活性化を表している（Neely, 1991）。 彼らはあらかじめ用意した強い意味関連語対（例： hot-cold）と弱い意味関連語対（例：crime-gun）を用 いて潜在的な連想活動のパタンを検討した。覚醒時お よび，NREM 睡眠直後には強い意味関連語に対する プライミング効果が大きく, 弱い意味関連語へのプラ イミング効果は小さかったが, REM 睡眠直後では弱 い意味関連語へのプライミング効果のみが起こった。 すなわち，NREM 睡眠中に起こる連想は覚醒時と同 様に意味的な関連が強いものと弱いものがあるのに対 し, REM 睡眠中には覚醒時に起こる強い意味的関連 を持った連想が消失し，弱い意味的関連に基づく連想 活動が活性化することを示している。この結果は, NREM 睡眠中の夢見体験は, 比較的覚醒時と変わら ない連想パタンにより内容が形成されるが, REM 睡 眠中には覚醒時に通常起こる強い意味的関連からなる 常識的な連想ネットワークが遮断され, 覚醒時には弱 い連想関係でしかなかった連想ネットワークだけが活 性化することにより, 突拍子のない, 意外性のあるス トーリーが夢に出力されることを示唆している。夢に よって文豪や芸術家がアイデアを得たという話は多い が, それは睡眠中に起こる, 覚醒中とは異なる連想パ タンによるものかもしれない。

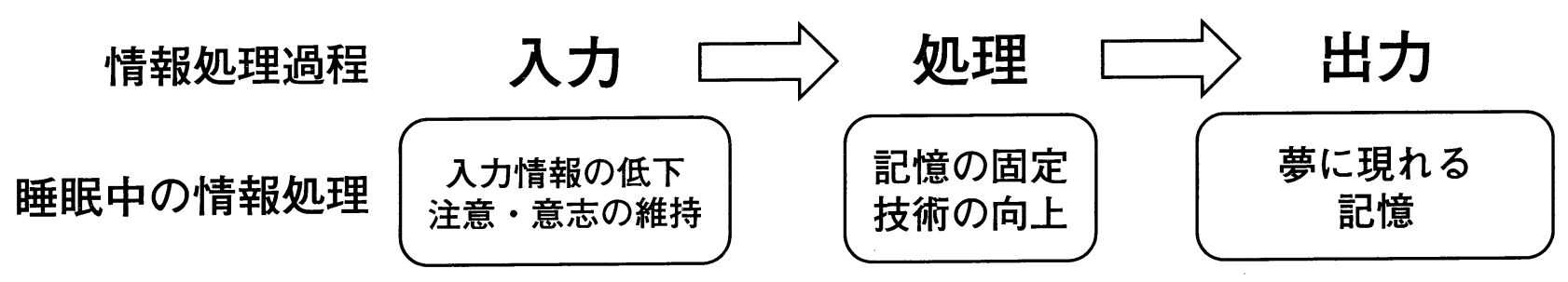

Figure 6. 睡眠中に行われる情報処理 


\section{おわりに}

本稿は睡眠中に行われる情報の入力, 操作と処理, 出力に関して概括した（Figure 6）。睡眠中に起こる入 力情報への反応減少は睡眠の特徵のなかでも主要なも のであり，覚醒時と比べ睡眠中の外部情報処理能力は 低下する。しかし，睡眠中でも注意・動機づけなど心 理的な処理機能は維持されていることが示されている。 睡眠中の情報処理と出力は, 覚醒時とは異なる独自の 機能, 特徵を持っている。特定の記憶向上は練習後の 睡眠無しには起こらず，多くの記憶にとつて練習後の 睡眠がその後の向上, 固定をもたらすことが明らかに なってきた。覚醒時に記銘された記憶は，覚醒時とは 異なる形で夢に出力される。そのため夢はアイデア, 芸術など人類の発展に無くてはならない創造性を生み 出す源であると言える。

人は人生の 3 分の 1 を眠りに費やす。その理由の一 つは覚醒時だけでなく，睡眠中にも情報処理を行う必 要があるからかもしれない。睡眠中の情報処理過程を さらに検討することにより，これまで覚醒状態を対象 とした研究では分からなかった人間の認知機能, 記憶, 思考といった心理学的問題に対して新たな理解が得ら れるものと考える。

\section{引用文献}

Atienza, M., Cantero, J.L., \& Stickgold, R. (2004). Posttraining sleep enhances automaticity in perceptual discrimination. Journal of Cognitive Neuroscience, 16, 53-64.

Badia, P., Harsh, J., Balkin, T., O’Rourke, D., \& Burton, S. (1985). Behavioral control of respiration in sleep and sleepiness due to signal-induced sleep fragmentation. Psychophysiology, 22, 517-524.

Benson, K., \& Feinberg, I. (1975). Sleep and memory: retention 8 and 24 hours after initial learning. Psychophysiology, 12, 192-195.

Benson, K., \& Feinberg, I. (1977). The beneficaial effect of sleep in an extended Jenkins and Dallenbach paradigm. Psychophysiology, 14, 375-384.

Cabeza, R., Prince, S.E., Daselaar, S.M., Greenberg, D.L., Budde, M., Dolcos, F., LaBar, K.S., \& Rubin, D.C. (2004). Brain activity during episodic retrieval of autobiographical and laboratory events: an fMRI study using a novel photo paradigm. Journal of Cognitive Neuroscience, 16, 1583-1594.

Cicogna, P., Natale, V., Occhionero, M., \& Bosinelli, M. (2000). Slow wave and REM sleep mentation. Sleep Research Online, 3, 67-72.

Cohen, D.A., Pascual-Leone, A., Press, D.Z., \& Robertson, E.M. (2005). Off-line learning of motor skill memory: a double dissociation of goal and movement. Proceedings of the National Academy of Sciences of the United States of America, 102, 18237-18241.

Fenn, K.M., Nusbaum, H.C., \& Margoliash, D. (2003) Consolidation during sleep of perceptual learning of spoken language. Nature, 425, 614-616.

Fischer, S., Drosopoulos, S., Tsen, J., \& Born, J. (2006) Implicit learning -- explicit knowing: a role for sleep in memory system interaction. Journal of Cognitive Neuroscience, 18, 311-319.

Fischer, S., Nitschke, M.F., Melchert, U.H., Erdmann, C., \& Born, J. (2005). Motor memory consolidation in sleep shapes more effective neuronal representations. The Journal of Neuroscience, 25, 11248-11255.

Fosse, M.J., Fosse, R., Hobson, J.A., \& Stickgold, R.J. (2003). Dreaming and episodic memory: a functional dissociation? Journal of Cognitive Neuroscience, 15, 19.

Fosse, R., Stickgold, R., \& Hobson, J.A. (2004). Thinking and hallucinating: reciprocal changes in sleep. Psychophysiology, 41, 298-305.

Gaab, N., Paetzold, M., Becker, M., Walker, M.P., \& Schlaug, G. (2004). The influence of sleep on auditory learning: a behavioral study. Neuroreport, 15, 731-734.

Gais, S., Molle, M., Helms, K., \& Born, J. (2002). Learning-dependent increases in sleep spindle density. The Journal of Neuroscience, 22, 6830-6834.

Gais, S., Plihal, W., Wagner, U., \& Born, J. (2000). Early sleep triggers memory for early visual discrimination skills. Nature Neuroscience, 12, 1335-1339.

Jenkins, J.G., \& Dallenbach, K.M. (1924). Oblivescence during sleep and waking. American Journal of Psychology, 35, 605-612.

Jouvet, M. (1992). Le sommeil et le reve. Paris: Editions Odile Jacob. (ジュヴェ M. 北浜邦夫（訳）(1997). 


\section{睡眠と夢 紀伊国屋書店)}

Karni, A., Tanne, D., Rubenstein, B.S., Askenasy, J. J., \& Sagi, D. (1994). Dependence on REM sleep of overnight improvement of a perceptual skill. Science, 265, 679682.

Kuriyama, K., Stickgold, R., \& Walker, M.P. (2004). Sleepdependent learning and motor-skill complexity. Learning \& Memory, 11, 705-713.

Langford, G.W., Meddis, R., \& Pearson, A.J. (1974). Awakening latency from sleep for meaningful and nonmeaningful stimuli. Psychophysiology, 11, 1-5.

Maquet, P., Laureys, S., Peigneux, P., Fuchs, S., Petiau, C., Phillips, C., Aerts, J., Del Fiore, G., Degueldre, C., Meulemans, T., Luxen, A., Franck, G., Van Der Linden, M., Smith, C., \& Cleeremans, A. (2000). Experiencedependent changes in cerebral activation during human REM sleep. Nature Neuroscience, 3, 831-836.

Marshall, L., Helgadottir, H., Molle, M., \& Born, J. (2006). Boosting slow oscillations during sleep potentiates memory. Nature. Nov 5 [Epub ahead of print].

Mednick, S., Nakayama, K., \& Stickgold, R. (2003). Sleepdependent learning: a nap is as good as a night. Nature Neuroscience, 6, 697-698.

Mednick, S.C., Nakayama, K., Cantero, J.L, Atienza, M., Levin, A.A., Pathak, N., \& Stickgold, R. (2002). The restorative effect of naps on perceptual deterioration. Nature Neuroscience, 5, 677-681.

宮城音弥 (1972). 夢 第二版 岩波書店

村上誠祥・森憲作 (2005). 睡眠・覚醒と視床・大脳皮 質での感覚ゲーティングＢrain Medical, 18, 25-32.

Neely, J. H. (1991). Semantic priming effects in visual word recognition: A selective review of current andings and theories. In D. Besner \& G. W. Humphreys (Eds.), Basic processes in reading: Visual word recognition. Hillsdale, NJ: Erlbaum. pp. 264-336.

Nielsen, T.A. (2004). Chronobiological features of dream production. Sleep Medicine Reviews, 8, 403-424.

Nielsen, T.A., Kuiken, D., Alain, G., Stenstrom, P., \& Powell, R.A. (2004). Immediate and delayed incorporations of events into dreams: further replication and implications for dream function. Journal of Sleep Research, 13, 327-336.
Nielsen, T.A., \& Stenstrom, P. (2005). What are the memory sources of dreaming? Nature, 437, 1286-9.

Okuma, T., Nakamura, K., Hayashi, A., \& Fujimori, M. (1966). Psychophysiological study on the depth of sleep in normal human subjects. Electroencephalography Clinical Neurophysiology, 21, 140-147.

Peigneux, P., Laureys, S., Fuchs, S., Destrebecqz, A., Collette, F., Delbeuck, X., Phillips, C., Aerts, J., Del Fiore, G., Degueldre, C., Luxen, A., Cleeremans, A., \& Maquet, P. (2003). Learned material content and acquisition level modulate cerebral reactivation during posttraining rapid-eye-movements sleep. Neuroimage, 20, 125-134.

Plihal, W. \& Born, J. (1997). Effects of early and late nocturnal sleep on declarative and procedural memory. Journal of Cognitive Neuroscience, 9, 534-547.

Rechtschaffen, A., Hauri, P., \& Zeitlin, M. (1966). Auditory awakening thresholds in REM and NREM sleep stages. Perceptual and Motor Skills, 22, 927-942.

Schabus, M., Gruber, G., Parapatics, S., Sauter, C., Klosch, G., Anderer, P., Klimesch, W., Saletu, B., \& Zeitlhofer, J. (2004). Sleep spindles and their significance for declarative memory consolidation. Sleep, 27, 1479-1485.

Stickgold, R. (2004). Dissecting sleep-dependent learning and memory consolidation. Comment on Schabus $\mathrm{M}$ et al. Sleep spindles and their significance for declarative memory consolidation. Sleep; 27(8): 1479-85. Sleep, 27, 1443-1445.

Stickgold, R., James, L., \& Hobson, J.A. (2000). Visual discrimination learning requires sleep after training. Nature Neuroscience, 3, 1237-1238.

Stickgold, R., Malia, A., Fosse, R., Propper, R., \& Hobson, J.A. (2001). Brain-mind states: I. Longitudinal field study of sleep/wake factors influencing mentation report length. Sleep, 24, 171-179.

Stickgold, R., Malia, A., Maguire, D., Roddenberry, D., \& O'Connor, M. (2000). Replaying the game: hypnagogic images in normals and amnesics. Science, 290, 350-353.

Stickgold, R., Scott, L., Rittenhouse, C., \& Hobson, J.A. (1999). Sleep-induced changes in associative memory. Journal of Cognitive Neuroscience, 11, 182-193.

Stickgold, R., Whidbee, D., Schirmer, B., Patel, V., \& 
Hobson, J.A. (2000). Visual discrimination task improvement: A multi-step process occurring during sleep. Journal of Cognitive Neuroscience. 12, 246-254. 鈴木博之 - 久我隆一 - 内山 真 (2002). 超短時間睡眠 覚醒スケジュールを用いた睡眠状態と夢見体験の検 討 生理心理学と精神生理学, 20, 19-28.

Suzuki, H., Uchiyama, M., Tagaya, H., Ozaki, A., Kuriyama, K., Aritake, S., Shibui, K., Tan, X., Kamei, Y., \& Kuga, R. (2004). Dreaming during non-rapid eye movement sleep in the absence of prior rapid eye movement sleep. Sleep, 27, 1486-1490.

Takahara, M., Nittono, H., \& Hori, T. (2006). Effect of voluntary attention on auditory processing during REM sleep. Sleep, 29, 975-982.

Takeuchi, T., Miyasita, A., Inugami, M., \& Yamamoto, Y. (2001). Intrinsic dreams are not produced without REM sleep mechanisms: evidence through elicitation of sleep onset REM periods. Journal of Sleep Research, 10, 4352.

Thompson, L.T., Moyer, J.R. Jr., \& Disterhoft, J.F. (1996). Transient changes in excitability of rabbit CA3 neurons with a time course appropriate to support memory consolidation. Journal of Neurophysiology, 76, 18361849.

Torda, C. (1969). Dreams of subjects with bilateral hippocampal lesions. Acta Psychiatrica Scandinavica, 45, 277-288.

Tulving, E. (1972). Episodic and semantic memory. In E. Tulving \& W. Donaldson (Eds.), Organization of memory. New York: Academic Press. pp. 382-403.

Tulving, E. (2002). Episodic memory: from mind to brain. Annual Review of Psychology, 53, 1-25.

Wagner, U., Gais, S., Haider, H., Verleger, R., \& Born, J. (2004). Sleep inspires insight. Nature, 427, 352-355.

Walker, M.P., Brakefield, T., Morgan, A., Hobson, J.A., \& Stickgold, R. (2002). Practice with sleep makes perfect: sleep-dependent motor skill learning. Neuron, 35, 205211.

Williams, H.L., Morlock, H.C. Jr., \& Morlock, J.V. (1966). Instrumental behavior during sleep. Psychophysiology, 2, 208-216.

Wyatt, J.K., Bootzin, R.R., Anthony, J., \& Bazant, S. (1994). Sleep onset is associated with retrograde and anterograde amnesia. Sleep, 17, 502-511. 